\title{
REFLEKSI TEKNOLOGI DALAM DIMENSI AGAMA
}

\author{
Zamakhsyari Abdul Majid \\ UIN Syarif Hidayatullah Jakarta, DPK. Pascasarjana UIA Jakarta \\ Email: zamakhsyari.am@gmail.com
}

\begin{abstract}
This paper aims to study and analyze the development of science and technology in a sustainable manner and its relation to the perspective of holistic, integrative and interconnective religious studies. This study uses a qualitativedescriptive method by trying to explore various works and writings related to the focus of the study, either directly or indirectly. The works are read carefully and then analyzed and interpreted qualitatively according to predetermined study problems. This research is a library research. The results of this paper show that science and technology, especially in modern times, have undergone many changes and are very fast, while religion is moving very slowly, because of that there is a disharmony between religion and science and technology. Science and religion, both in order to reinforce existing knowledge with the arguments in the Quran, or vice versa, make science an explanation of the Quran.
\end{abstract}

Key Word : Technology, Epistemology of Religion, Al-Quran

\begin{abstract}
Abstrak
Tulisan ini bertujuan untuk mengkaji dan menganalisa perkembangan ilmu pengetahuan dan teknologi secara berkelanjutan dan kaitanya dengan sudut pandang kajian keilmuan keagamaan yang holistik, integratif dan interkonektif. Penelitian ini menggunakan metode kualitatif-diskriptif dengan mencoba menelusuri berbagai karya dan tulisan yang berhubungan dengan fokus kajian, baik secara langsung maupun tidak langsung. Karya-karya itu dibaca secara seksama lalu dianalis dan diinterpretasi secara kualitatif mengikut permasalahan kajian yang sudah ditentukan sebelumnya. Penelitian ini merupakan penelitian kepustakaan. Hasil tulisan ini menunjukkan Ilmu pengetahuan dan teknologi terutama pada zaman modern ini, mengalami banyak perubahan dan sangat cepat, sedang agama bergerak dengan lamban sekali, karena itu terjadi ketidak harmonisan antara agama dan ilmu pengetahuan serta teknologi. Ilmu pengetahuan dengan agama, baik dalam rangka untuk mempertegas keilmuan yang sudah ada dengan dalil-dalil dalam al-Qur'an, maupun sebaliknya menjadikan sains sebagai penjelas terhadap al-Qur'an.
\end{abstract}

Kata Kunci: Teknologi, Epistimologi Agama, Al-Quran 


\section{Pendahuluan}

Perkembangan ilmu pengetahuan dan teknologi (iptek) di satu sisi memang berdampak positif, yakni dapat memperbaiki kualitas hidup manusia. Berbagai sarana modern industri, komunikasi, dan transportasi, misalnya, terbukti amat bermanfaat. Dengan ditemukannya mesin jahit, dalam 1 menit bisa dilakukan sekitar 7000 tusukan jarum jahit. Bandingkan kalau kita menjahit dengan tangan, hanya bisa 23 tusukan per menit. ${ }^{1}$ Dahulu Ratu Isabella (Italia) di abad XVI perlu waktu 5 bulan dengan sarana komunikasi tradisional untuk memperoleh kabar penemuan benua Amerika oleh Columbus. Lalu di abad XIX Orang Eropa perlu 2 minggu untuk memperoleh berita pembunuhan Presiden Abraham Lincoln. Tapi pada 1969, dengan sarana komunikasi canggih, dunia hanya perlu waktu 1,3 detik untuk mengetahui kabar pendaratan Neil Amstrong di bulan. ${ }^{2}$

Dulu orang naik haji dengan kapal laut bisa memakan waktu 17-20 hari untuk sampai ke Jeddah. Sekarang dengan naik pesawat terbang, kita hanya perlu 12 jam saja. Tapi di sisi lain, tak jarang iptek berdampak negatif karena merugikan dan membahayakan kehidupan dan martabat manusia. Bom atom telah menewaskan ratusan ribu manusia di Hiroshima dan Nagasaki pada tahun 1945. Pada tahun 1995, Elizabetta, seorang bayi Italia, lahir dari rahim bibinya setelah dua tahun ibunya (bernama Luigi) meninggal. Ovum dan sperma orang tuanya yang asli, ternyata telah disimpan di "bank" dan kemudian baru dititipkan pada bibinya, Elenna adik Luigi. Bayi tabung di Barat bisa berjalan walau pun asal usul sperma dan ovumnya bukan dari suami isteri. ${ }^{3}$ Bioteknologi dapat digunakan untuk mengubah mikroorganisme yang sudah berbahaya, menjadi lebih berbahaya, misalnya mengubah sifat genetik virus influenza hingga mampu membunuh manusia dalam beberapa menit saja. ${ }^{4}$ Kloning hewan rintisan Ian Willmut yang sukses menghasilkan domba kloning bernama Dolly, dicoba untuk diterapkan pada manusia (human cloning). Lingkungan hidup seperti laut, atmosfer udara, dan hutan juga tak sedikit mengalami kerusakan dan pencemaran yang sangat parah dan berbahaya. Beberapa varian tanaman pangan hasil rekayasa genetika juga diindikasikan berbahaya bagi kesehatan manusia. Tak sedikit yang memanfaatkan teknologi internet sebagai sarana untuk melakukan kejahatan dunia maya (cyber crime) dan untuk mengakses pornografi, kekerasan, dan perjudian.

Di sinilah, peran agama sebagai pedoman hidup menjadi sangat penting untuk ditengok kembali. Dapatkah agama memberi tuntunan agar kita memperoleh dampak iptek yang positif saja, seraya mengeliminasi dampak

\footnotetext{
${ }^{1}$ Yusuf Qardhawi, Norma dan Etika Ekonomi Islam. (Jakarta: Gema Insani Press, 1997). h, 35

${ }^{2}$ Budi Winarto, Globalisasi Wujud Imperialisme Baru, (Yogyakarta: Tajidu Press, 2004), h. 125

${ }^{3}$ Syeichul Hadipermono, Bayi Tabung dan Rekayasa Genetika, (Surabaya: Wali Demak Press, 19995), h. 18

${ }^{4}$ Nurchalis Bakry et.al,. 1996. Bioteknologi dan Al-Qur'an Referensi Dakwah Dai Modern (Jakarta: Gema Insani Press, 1996), h. 26
} 
negatifnya semiminal mungkin? Sejauh manakah agama Islam dapat berperan dalam mengendalikan perkembangan teknologi modern? Tulisan ini bertujuan menjelaskan peran Islam dalam perkembangan dan pemanfaatan teknologi tersebut.

\section{Metodologi}

Penelitian ini menggunakan metode kualitatif-diskriptif dengan mencoba menelusuri berbagai karya dan tulisan yang berhubungan dengan fokus kajian, baik secara langsung maupun tidak langsung. Karya-karya itu dibaca secara seksama lalu dianalis dan diinterpretasi secara kualitatif mengikut permasalahan kajian yang sudah ditentukan sebelumnya. Penelitian ini merupakan penelitian kepustakaan ${ }^{5}$.

Ada empat ciri penelitian kepustakaan, yaitu: 1) penelitian berhadapan langsung dengan teks (naskah) atau data angka dan bukan dengan pengetahuan langsung dari lapangan atau saksi mata (eye witness) berupa kejadian, orang atau benda lainnya, 2) data pustaka bersifat siap pakai (ready mode), 3) data perpustakaan umumnya sumber sekunder dan 4) data pustaka tidak dibatasi oleh ruang dan waktu karena ia sudah merupakan data "mati" yang tersimpan dalam rekaman tertulis. Maka dalam penelitian ini menggunakan penelitian kepustakaan ${ }^{6}$.

\section{Pembahasan}

\section{Epistimologi Agama Terhadap Teknologi}

Untuk memperjelas, akan disebutkan dulu beberapa pengertian dasar Ilmu pengetahuan (sains) adalah pengetahuan tentang gejala alam yang diperoleh melalui proses yang disebut metode ilmiah (scientific method). ${ }^{7}$ Sedang teknologi adalah pengetahuan dan keterampilan yang merupakan penerapan ilmu pengetahuan dalam kehidupan manusia sehari-hari. Perkembangan iptek, adalah hasil dari segala langkah dan pemikiran untuk memperluas, memperdalam, dan mengembangkan iptek. ${ }^{8}$ Agama yang dimaksud di sini, adalah agama Islam, yaitu agama yang diturunkan Allah SWT kepada Nabi Muhammad SAW, untuk mengatur hubungan manusia dengan Penciptanya (dengan aqidah dan aturan ibadah), hubungan manusia dengan dirinya sendiri (dengan aturan akhlak, makanan, dan pakaian), dan hubungan manusia dengan manusia lainnya (dengan aturan mueamalah dan uqubat/sistem pidana). ${ }^{9}$

Bagaimana hubungan agama dan iptek? Secara garis besar, berdasarkan tinjauan ideologi yang mendasari hubungan keduanya, terdapat 3 (tiga) jenis

${ }^{5}$ Amin, A. R. M. (2014). Prinsip Dan Fenomena Moderasi Islam Dalam Tradisihukum Islam Moderat Islam, Its Principle And Issues In Islamic Law Tradition. AlQalam, 20, 23-32.

${ }^{6}$ Fahri, M., \& Zainuri, A. (2020). Moderasi Beragama Di Indonesia. Intizar2, 25 (2). Https://Doi.Org/Https://Doi.Org/10.19109/Intizar.V25i2.5640

${ }^{7}$ Jujun Suriasumantri, S. Ilmu Dalam Perspektif Moral, Sosial, dan Politik. (Jakarta: PT Gramedia, 1986), h. 52

${ }^{8}$ Bustanudin Agus, Pengembangan Ilmu-Ilmu Sosial : Studi Banding Antara Pandangan Ilmiah dan Ajaran Islam, (Jakarta: Gema Insani Press, 1999), h. 29

${ }^{9}$ Taqiyuddin An-Nabhani,. Nizham Al-Islam, (ttp: Hizbut Tahrir, 2001) hal, 
paradigma $:^{10}$ Pertama, paradagima sekuler, yaitu paradigma yang memandang agama dan iptek adalah terpisah satu sama lain. Sebab, dalam ideologi sekularisme Barat, agama telah dipisahkan dari kehidupan (fashl al-din ,an alhayah). Agama tidak dinafikan eksistensinya, tapi hanya dibatasi perannya dalam hubungan pribadi manusia dengan tuhannya. Agama tidak mengatur kehidupan umum/publik. Paradigma ini memandang agama dan iptek tidak bisa mencampuri dan mengintervensi yang lainnya. Agama dan iptek sama sekali terpisah baik secara ontologis (berkaitan dengan pengertian atau hakikat sesuatu hal), epistemologis (berkaitan dengan cara memperoleh pengetahuan), dan aksiologis (berkaitan dengan cara menerapkan pengetahuan).

Paradigma ini mencapai kematangan pada akhir abad XIX di Barat sebagai jalan keluar dari kontradiksi ajaran Kristen (khususnya teks Bible) dengan penemuan ilmu pengetahuan modern. Semula ajaran Kristen dijadikan standar kebenaran ilmu pengetahuan. Tapi ternyata banyak ayat Bible yang berkontradiksi dan tidak relevan dengan fakta ilmu pengetahuan. Contohnya, menurut ajaran gereja yang resmi, bumi itu datar seperti halnya meja dengan empat sudutnya. Padahal faktanya, bumi itu bulat berdasarkan penemuan ilmu pengetahuan yang diperoleh dari hasil pelayaran Magellan. Dalam Bible dikatakan: "Kemudian dari pada itu, aku melihat empat malaikat berdiri pa da keempat penjuru angin bumi dan mereka menahan keempat angin bumi, supaya jangan ada angin bertiup di darat, atau di laut, atau di pohon-pohon." (Wahyuwahyu 7: 1). Kalau konsisten dengan teks Bible, maka fakta sains bahwa bumi bulat tentu harus dikalahkan oleh teks Bible (Adian Husaini, Mengapa Barat Menjadi Sekular-Liberal, www.insistnet.com). Ini tidak masuk akal dan problematis. Maka, agar tidak problematis, ajaran Kristen dan ilmu pengetahuan akhirnya dipisah satu sama lain dan tidak boleh saling intervensi.

Kedua, paradigma sosialis, yaitu paradigma dari ideologi sosialisme yang menafikan eksistensi agama sama sekali. Agama itu tidak ada, dus, tidak ada hubungan dan kaitan apa pun dengan iptek. Iptek bisa berjalan secara independen dan lepas secara total dari agama. Paradigma ini mirip dengan paradigma sekuler di atas, tapi lebih ekstrem. Dalam paradigma sekuler, agama berfungsi secara sekularistik, yaitu tidak dinafikan keberadaannya, tapi hanya dibatasi perannya dalam hubungan vertikal manusia-tuhan. Sedang dalam paradigma sosialis, agama dipandang secara ateistik, yaitu dianggap tidak ada (in-exist) dan dibuang sama sekali dari kehidupan.

Paradigma tersebut didasarkan pada pikiran Karl Marx (w.1883) yang ateis dan memandang agama (Kristen) sebagai candu masyarakat, karena agama menurutnya membuat orang terbius dan lupa akan penindasan kapitalisme yang kejam. Karl Marx mengatakan: "Religion is the sigh of the oppressed creature, the heart of the heartless world, just as it is the spirit of a spiritless situation. It is $t$ he opium of the people." (Agama adalah keluh-kesah makhluk tertindas, jiwa dari suatu dunia yang tak berjiwa, sebagaimana ia merupakan ruh/spirit dari situasi yang tanpa ruh/spirit. Agama adalah candu bagi rakyat). ${ }^{11}$

${ }^{10}$ Hasan Farghal, Pokok Pikiran Tentang Hubungan Ilmu Dengan Agama,(tt, 1994), h. 99- 119

11 Andi Muawiyah Ramly, Peta Pemikiran Karl Marx [Materialisme Dialektis dan Materialisme Historis] , (Yogyakarta: LkiS, 2000), h. 165-166 
Berdasarkan paradigma sosialis ini, maka agama tidak ada sangkut pautnya sama sekali dengan iptek. Seluruh bangunan ilmu pengetahuan dalam paradigma sosialis didasarkan pada ide dasar materialisme, khususnya Materialisme Dialektis. ${ }^{12}$ Paham Materialisme Dialektis adalah paham yang memandang adanya keseluruhan proses perubahan yang terjadi terus menerus melalui proses dialektika, yaitu melalui pertentangan-pertentangan yang ada pada materi yang sudah mengandung benih perkembanganitu sendiri. ${ }^{13}$

Ketiga, paradigma Islam, yaitu paradigma yang memandang bahwa agama adalah dasar dan pengatur kehidupan. Aqidah Islam menjadi basis dari segala ilmu pengetahuan Aqidah Islam yang terwujud dalam apa-apa yang ada dalam AlQur`an dan Al-Hadits menjadi qa"idah fikriyah (landasan pemikiran), yaitu suatu asas yang di atasnya dibangun seluruh bangunan pemikiran dan ilmu pengetahuan manusia. ${ }^{14}$

Paradigma ini memerintahkan manusia untuk membangun segala pemikirannya berdasarkan Aqidah Islam, bukan lepas dari aqidah itu. Ini bisa kita pahami dari ayat yang pertama kali turun (artinya): "Bacalah dengan (menyebut) nama Tuhanmu Yang menciptakan.” (QS Al-,Alaq [96] : 1). Ayat ini berarti manusia telah diperintahkan untuk membaca guna memperoleh berbagai pemikiran dan pemahaman. Tetapi segala pemikirannya itu tidak boleh lepas dari Aqidah Islam, karena iqra' haruslah dengan bismi rabbika, yaitu tetap berdasarkan iman kepada Allah, yang merupakan asas Aqidah Islam (Al-Qashash, 1995:81).

Paradigma Islam ini menyatakan bahwa, kata putus dalam ilmu pengetahuan bukan berada pada pengetahuan atau filsafat manusia yang sempit, melainkan berada pada ilmu Allah yang mencakup dan meliputi segala sesuatu. ${ }^{15}$ Firman Allah SWT (artinya): "Dan adalah (pengetahuan) Allah Maha Meliputi segala sesuatu." (QS An-Nisaa' [4] : 126). "Dan sesungguhnya Allah, ilmu-Nya benar-benar melip uti segala sesuatu." (QS Ath-Thalaq [65]: 12)

Itulah paradigma yang dibawa Rasulullah SAW (w. $632 \mathrm{M}$ ) yang meletakkan Aqidah Islam yang berasas Laa ilaaha illallah Muhammad Rasulullah sebagai asas ilmu pengetahuan. Beliau mengajak memeluk Aqidah Islam lebih dulu, lalu setelah itu menjadikan aqidah tersebut sebagai pondasi dan standar bagi berbagai pengetahun. Ini dapat ditunjukkan misalnya dari suatu peristiwa ketika di masa Rasulullah SAW terjadi gerhana matahari, yang bertepatan dengan wafatnya putra beliau (Ibrahim). Orang-orang berkata."Gerhana matahari ini terjadi karena meninggalnya Ibrahim." Maka Rasulullah SAW segera menjelaskan: "Sesungguhnya gerhana matahari dan bulan tidak terj adi karena kematian atau kelahiran seseorang, akan teta pi keduanya termasuk tanda-tanda kekuasaan Allah. Dengannya All ah memperingatkan hamba-hamba-Nya..." (HR. Al-Bukhari dan AnNasài). ${ }^{16}$

Dengan jelas kita tahu bahwa Rasulullah SAW telah meletakkan Aqidah Islam sebagai dasar ilmu pengetahuan, sebab beliau menjelaskan, bahwa fenomena alam adalah tanda keberadaan dan kekuasaan Allah, tidak ada

\footnotetext{
${ }^{12}$ Hasan Farghal, op. cit., h. 112

${ }^{13}$ Ibid, h. 110

${ }^{14}$ An Nabhani, op. cit, h., 45

${ }^{15}$ Hasan Farghal, op. cit., h. 68

16 Abdurrahman Al-Baghdadi, Sistem Pendidikan di Masa Khilafah Islam, (Bagil: AlIzzah, 1996), h. 10
} 
hubungannya dengan nasib seseorang. Hal ini sesuai dengan aqidah muslim yang tertera dalam Al-Qur’an (artinya): "Sesungguhnya dalam penciptaan langit dan bumi dan silih berganti nya malam dan siang terdapat tanda-tanda (kekuasaan Allah) bagi orang-orang yang berakal.” (QS Ali „Imran [3]: 190)

Inilah paradigma Islam yang menjadikan Aqidah Islam sebagai dasar segala pengetahuan seorang muslim. Paradigma inilah yang telah mencetak muslim-muslim yang taat dan shaleh tapi sekaligus cerdas dalam iptek. Itulah hasil dan prestasi cemerlang dari paradigma Islam ini yang dapat dilihat pada masa kejayaan iptek Dunia Islam antara tahun 700-1400 M. Pada masa inilah dikenal nama Jabir bin Hayyan (w. 721) sebagai ahli kimia termasyhur, AlKhawarzmi (w. 780) sebagai ahli matematika dan astronomi, Al-Battani (w. 858) sebagai ahli astronomi dan matematika, Al-Razi (w. 884) sebagai pakar kedokteran, ophtalmologi, dan kimia, Tsabit bin Qurrah (w. 908) sebagai ahli kedokteran dan teknik, dan masih banyaklagi. ${ }^{17}$

\section{Teknologi Sebagai Fundamentalisme Keislaman}

Inilah peran pertama yang dimainkan Islam dalam iptek, yaitu aqidah Islam harus dijadikan basis segala konsep dan aplikasi iptek. Inilah paradigma Islam sebagaimana yang telah dibawa oleh Rasulullah SAW. Paradigma Islam inilah yang seharusnya diadopsi oleh kaum muslimin saat ini. Bukan paradigma sekuler seperti yang ada sekarang. Diakui atau tidak, kini umat Islam telah telah terjerumus dalam sikap membebek dan mengekor Barat dalam segalagalanya; dalam pandangan hidup, gaya hidup, termasuk dalam konsep ilmu pengetahuan.

Bercokolnya paradigma sekuler inilah yang bisa menjelaskan, mengapa di dalam sistem pendidikan yang diikuti orang Islam, diajarkan sistem ekonomi kapitalis yang pragmatis serta tidak kenal halal haram. Eksistensi paradigma sekuler itu menjelaskan pula mengapa tetap diajarkan konsep pengetahuan yang bertentangan dengan keyakinan dan keimanan muslim. Misalnya Teori Darwin yang dusta dan sekaligus bertolak belakang dengan Aqidah Islam.

Kekeliruan paradigmatis ini harus dikoreksi. Ini tentu perlu perubahan fundamental dan perombakan total. Dengan cara mengganti paradigma sekuler yang ada saat ini, dengan paradigma Islam yang memandang bahwa Aqidah Islam (bukan paham sekularisme) yang seharusnya dijadikan basis bagi bangunan ilmu pengetahuan manusia.

Namun di sini perlu dipahami dengan seksama, bahwa ketika Aqidah Islam dijadikan landasan iptek, bukan berarti konsep-konsep iptek harus bersumber dari Al-Qur`an dan Al-Hadits, tapi maksudnya adalah konsep iptek harus distandardisasi benar salahnya dengan tolok ukur AlQur`an dan Al-Hadits dan tidak boleh bertentangan dengan keduanya. ${ }^{18}$

Jika kita menjadikan Aqidah Islam sebagai landasan iptek, bukan berarti bahwa ilmu astronomi, geologi, agronomi, dan seterusnya, harus didasarkan pada ayat tertentu, atau hadis tertentu. Kalau pun ada ayat atau hadis yang cocok dengan fakta sains, itu adalah bukti keluasan ilmu Allah yang meliputi segala sesuatu (lihat QS. An-Nisaa

\footnotetext{
${ }^{17}$ Hossein Bahreisj, Menengok Kejayaan Islam, (Surabaya: PT. Bina Ilmu,1995), h. 28

${ }^{18}$ Al Baghdadi, op. cit., h. 12
} 
[4]:126 dan QS AthThalaq [65]:12), bukan berarti konsep iptek harus bersumber pada ayat atau hadis tertentu. Misalnya saja dalam astronomi ada ayat yang menjelaskan bahwa matahari sebagai pancaran cahaya dan panas (QS Nuh [71]: 16), bahwa langit (bahan alam semesta) berasal dari asap (gas) sedangkan galaksi-galaksi tercipta dari kondensasi (pemekatan) gas tersebut (QS. Fushshilat [41]: 11-12), dan seterusnya. Ada sekitar 750 ayat dalam AlQur`an yang semacam ini. ${ }^{19}$ Ayat-ayat ini menunjukkan betapa luasnya ilmu Allah sehingga meliputi segala sesuatu, dan menjadi tolok ukur kesimpulan iptek, bukan berarti bahwa konsep iptek wajib didasarkan pada ayat-ayat tertentu.

Jadi, yang dimaksud menjadikan Aqidah Islam sebagai landasan iptek bukanlah bahwa konsep iptek wajib bersumber kepada AlQur'an dan Al-Hadits, tapi yang dimaksud, bahwa iptek wajib berstandar pada Al-Qur`an dan Al-Hadits. Ringkasnya, Al-Qur`an dan AlHadits adalah standar (miqyas) iptek, dan bukannya sumber (mashdar) iptek. Artinya, apa pun konsep iptek yang dikembangkan, harus sesuai dengan AlQur`an dan Al-Hadits, dan tidak boleh bertentangan dengan Al-Qur`an dan AlHadits itu.

Jika suatu konsep iptek bertentangan dengan Al-Qur`an dan AlHadits, maka konsep itu berarti harus ditolak. Misalnya saja Teori Darwin yang menyatakan bahwa manusia adalah hasil evolusi dari organisme sederhana yang selama jutaan tahun berevolusi melalui seleksi alam menjadi organisme yang lebih kompleks hingga menjadi manusia modern sekarang. Berarti, manusia sekarang bukan keturunan manusia pertama, Nabi Adam AS, tapi hasil dari evolusi organisme sederhana. Ini bertentangan dengan firman Allah SWT yang menegaskan, Adam AS adalah manusia pertama, dan bahwa seluruh manusia sekarang adalah keturunan Adam AS itu, bukan keturunan makhluk lainnya sebagaimana fantasi Teori Darwin. ${ }^{20}$

Firman Allah SWT (artinya):

"(Dialah Tuhan) yang memulai penciptaan manusia dari tanah, kemudian Dia menciptakan keturunannya dari sari pati air yang hina (mani)." (QS AsSajdah [32]: 7). "Hai manusia, sesungguhnya Kami menciptakan kamu dari seorang laki-laki dan seorang perempuan dan me njadikan kamu berbangsa-bangsa dan bersuku-suku supaya kamu saling kenal mengenal." (QS Al-Hujuraat [49]: 13).

Implikasi lain dari prinsip ini, yaitu Al-Qur`an dan Al-Hadits hanyalah standar iptek, dan bukan sumber iptek, adalah bahwa umat Islam boleh mengambi iptek dari sumber kaum non muslim (orang kafir). Dulu Nabi SAW menerapkan penggalian parit di sekeliling Madinah, padahal strategi militer itu berasal dari tradisi kaum Persia yang beragama Majusi. Dulu Nabi SAW juga pernah memerintahkan

\footnotetext{
${ }^{19}$ Ibid, h. 113

${ }^{20}$ Abdul Qadim Zallum, Demokrasi Sistem Kufur: Haram Mengambil, Menerapkan, dan Menyebarluaskannya, (Bogor: Pustaka Thariqul Izzah, 2001), h. 75
} 
dua sahabatnya memepelajari teknik persenjataan ke Yaman, padahal di Yaman dulu penduduknya adalah Ahli Kitab (Kristen). Umar bin Khatab pernah mengambil sistem administrasi dan pendataan Baitul Mal (Kas Negara), yang berasal dari Romawi yang beragama Kristen. Jadi, selama tidak bertentangan dengan aqidah dan syariah Islam, iptek dapat diadopsi dari kaum kafir.

Sejarah telah membuktikan, bahwa kemajuan ilmu pengetahuan di dunia modern menjadi fakta sejarah yang tidak terbantahkan, bahkan banyak yang berpendapat bahwa ilmu pengetahuan bermula dari dunia Islam yang kemudian mengalami transmisi (penyebaran) dan poliferasi (pengembangan) ke dunia Barat yang sebelumnya dunia Barat dilanda dark ages (masa kegelapan) sehingga muncul zaman enlightenment (yang cerah) di Eropa.

Umat Islam sejak 14 abad silam turut mewarnai peradaban dunia, bahkan pesatnya perkembangan Islam ke Barat dan Timur membuat peradaban Islam dianggap sebagai peradaban yang paling besar pengaruhnya di dunia. Dari rentetan sumbangsi ilmuwan-ilmuwan Muslim, mulai ilmu agama sampai kepada ilmu pengetahuan alam dari sini terlihat bahwa Islam sangat berjasa dalam rangka menyatukan akal dengan alam, menetapkan kemandirian akal, menetapkan keberadaan hukum alam yang pasti atas kehendak Allah SWT, serta telah mampu mendamaikan akal dengan iman dan filsafat dengan agama sedangkan bangsa Barat masih membuat stereotip yang memisahkan antara akal dan iman serta filsafat dengan agama. Bahkan di dunia ilmu hukum, hukum Islam juga tidak dapat dibantahkan, ikut turut serta memberikan konstribusi dalam pembentukkan dan perkembangan hukum di zaman modern saat ini.

\section{Kesimpulan}

Ilmu pengetahuan dan agama melahirkan integrasi dan interkoneksi keilmuan yang menggambarkan adanya penyatuan atau pemaduan (integrasi) dan penghubungan (interkoneksi) antara "ilmu pengetahuan umum (sain) dan "ilmu pengetahuan agama". Dalam perspektif lain, integrasi dan interkoneksi sains dan agama dapat dipahami sebagai upaya untuk mempertemukan dan mendialogkan antara ilmu pengetahuan dengan agama, baik dalam rangka untuk mempertegas keilmuan yang sudah ada dengan dalil -dalil dalam alQur'an, maupun sebaliknya menjadikan sains sebagai penjelas terhadap al-Qur'an. Hal ini menunjukkan bahwa integrasi ilmu pengetahuan dan agama dipahami sebagai langkah strategis untuk mempertemukan khazanah dua keilmuan secara sinergis.

Ilmu pengetahuan dan teknologi terutama pada zaman modern ini, mengalami banyak perubahan dan sangat cepat, sedang agama bergerak dengan lamban sekali, karena itu terjadi ketidak harmonisan antara agama dan ilmu pengetahuan serta teknologi. Dalam ensiklopedi Agama dan filsafat dijelaskan bahwa Islam adalah agama Allah yang diperintahkan-Nya untuk mengajarkan tentang pokok-pokok serta peraturan-peraturannya kepada Nabi Muhammad saw. dan menugaskannya untuk menyampaikan agama tersebut kepada seluruh 
manusia dengan mengajak mereka untuk memeluknya. Salah satu ciri yang membedakan Islam dengan yang lainnya adalah penekanannya terhadap ilmu (sains). Al-Qur'an dan Al-Sunnah mengajak kaum muslimin untuk mencari dan mendapatkan ilmu dan kearifan, serta menempatkan orang-orang yang berpengatahuan pada derajat yang tinggi. Apabila kita memperhatikan ayat al-Qur'an mengenai perintah menuntut ilmu kita akan temukan bahwa perintah itu bersifat umum, tidak terkecuali pada ilmu-ilmu yang disebut ilmu agama, yang ditekankan dalam al-Qur'an adalah apakah ilmu itu bermanfaat atau tidak. Adapun kriteria ilmu yang bermanfaat adalah ilmu yang ditujukan untuk mendekatkan diri kepada sang khalik sebagai bentuk pengabdian kepada-Nya.

Pertemuan kaum muslimin dengan dunia modern, melahirkan berbagai aliran pemikiran, seperti aliran salaf dengan semboyan "Kembali kepada al-Qur'an dan Sunnah", dan aliran Tajdid dengan semboyan "maju ke depan bersama al-Qur'an". Pembaruan dalam Islam memang sangat dianjurkan selama pembaruan itu tidak mengebiri ajaran-ajaran Islam yang otentik, akan tetapi justru memperkuat, mempertinggi dan mengangkat martabat ummat Islam dihadapan bangsabangsa lain di dunia

\section{Daftar Pustaka}

Amin, A. R. M. (2014). Prinsip Dan Fenomena Moderasi Islam Dalam Tradisihukum Islam Moderat Islam, Its Principle And Issues In Islamic Law Tradition. Al-Qalam,.

Al-Baghdadi, Abdurrahman. Sistem Pendidikan di Masa Khilafah Islam. Bagil: Al-Izzah, 1996.

An-Nabhani, Taqiyuddin. Nizham Al-Islam. ttp: Hizbut Tahrir, 2001.

Bahreisj, Hossein. Menengok Kejayaan Islam. Surabaya : PT. Bina Ilmu, 1995.

Bakry, Nurchalis et.al. Bioteknologi dan Al-Qur'an Referensi Dakwah Dai Modern. Jakarta : Gema Insani Press, 1996.

Farghal, Hasan. Pokok Pikiran Tentang Hubungan Ilmu Dengan Agama. Ttp, 1994.

Fahri, M., \& Zainuri, A. (2020). Moderasi Beragama Di Indonesia. Intizar2,

Https://Doi.Org/Https://Doi.Org/10.19109/Intizar.V25i2.5640

Hadipermono, Syeichul. Bayi Tabung dan Rekayasa Genetika. Surabaya : Wali Demak Press, 1995.

Qaradhawi, Yusuf. Norma dan Etika Ekonomi Islam. Jakarta: Gema Insani Press, 1997.

Ramly, Andi Muawiyah. Peta Pemikiran Karl Marx [Materialisme Dialektis dan Materialisme Historis] . Yogyakarta : LkiS, 2000.

Suriasumantri, Jujun S. Ilmu Dalam Perspektif Moral, Sosial, dan Politik. Jakarta : PT Gramedia, 1986.

Winarno, Budi. Globalisasi Wujud Imperialisme Baru. Yogyakarta: Tajidu Press, 2004. 
Zallum, Abdul Qadim. Demokrasi Sistem Kufur : Haram Mengambil, Menerapkan, dan Menyebarluaskannya. Bogor: Pustaka Thariqul Izzah, 2001. 